\title{
Contemporary consequences of the 1967 Referendum
}

\author{
Brooke Ottley
}

University of Technology Sydney, Faculty of Arts and Social Sciences, PO Box 123, Ultimo NSW 2007, Australia.Brooke.E.Ottley@student.uts.edu.au

\begin{abstract}
The 1967 Australian Referendum and subsequent constitutional reform are widely considered a victory for Aboriginal and Torres Strait Islander people and an elevating moment in Australia's history. However, this analysis reveals the Referendum was in some ways an anticlimax, enabling paternalistic policies and exploitation of the First Peoples of Australia.
\end{abstract}

Key words Australian politics; NT Intervention; CDEP; white paternalism; selfdetermination

The 1967 Referendum to enumerate and legislate for Aboriginal and Torres Strait Islander people was hailed as a resounding success due to its near-unanimous voter support. There were high expectations that it would have a significant and positive impact on Aboriginal and Torres Strait Islander people, partly due to an extensive decade-long campaign to vote in support of the proposed constitutional reforms (McGregor 2009). Nevertheless, the Referendum's perceived benefit to Aboriginal and Torres Strait Islander people was perhaps overstated, its implications misunderstood, and the potential for misuse of the powers it bestowed on the federal government was possibly underestimated. The 1967 Referendum has done little to address disadvantage, systemic oppression and power imbalances between Indigenous and non-Indigenous Australia, particularly in relation to white Australians and the federal government maintaining their role as benevolent benefactors.

This essay will discuss a variety of paternalistic and sometimes punitive federal government policies imposed on Aboriginal and Torres Strait Islander people since the 1967 Referendum, with a focus on the 25 years to 2019. It will include the author's perspective as an Aboriginal and Torres Strait Islander person who has first-hand experience with some of the policies being discussed. It will critically analyse: a government educational benefit, ABSTUDY, and the inefficiency and lack of transparency in its administration; the racially discriminatory 
Community Development Employment Program (CDEP) and its ineffectiveness at achieving its goal of alleviating economic disparity; the 2007 Northern Territory National Emergency Response ('the Intervention') and subsequent use of the military to oppress Aboriginal people; BasicsCard, a tool for quarantining welfare payments, piloted in remote Aboriginal communities in the Northern Territory (NT); and the failures of the NT's Banned Drinker Register (BDR) in regulating the sale of alcohol.

Study assistance for Aboriginal and Torres Strait Islander people was first introduced in 1969, following the 1967 Referendum (Richardson 1998). It was not until 1988 that it was given its current name, the Aboriginal Study Assistance Scheme, or 'ABSTUDY', and it has undergone several revisions since. In 1998, there were no avenues for ABSTUDY recipients to appeal decisions made by welfare agency Centrelink (Richardson 1998). In this respect, Aboriginal and Torres Strait Islander students were afforded fewer rights than their nonIndigenous counterparts, who were allowed to request an external review of their eligibility for the equivalent student benefit, Austudy, by a tribunal or court (Richardson 1998). This discriminatory measure operated as a barrier to Aboriginal and Torres Strait Islander peoples' educational success and rendered them passive objects affected by, but having no agency over a government department's decisions about their lives.

In her discussion on 'Indigenous exceptionalism', Langton claimed that 'Aboriginal people are not required to be normal, such as attending school regularly, or competing in a meritocracy' (2013, p. 2). I argue that Aboriginal and Torres Strait Islander people are often required to demonstrate merit in order to access the opportunities offered to them. In the case of ABSTUDY, simply being an Aboriginal and/or Torres Strait Islander student is not sufficient to qualify for fortnightly study assistance. Aboriginal and Torres Strait Islander students must provide evidence of financial need via a thorough income and assets test, as well as satisfying a range of other criteria which also apply to non-Indigenous students (Australian Government Department of Human Services 2019a). For myself, this entailed providing at least 58 pages of forms and documents to prove my eligibility. Moreover, a Centrelink staff member also actively discouraged me from applying for ABSTUDY when I requested copies of the relevant forms.

Today, ABSTUDY applicants are not provided with the option of applying for assistance online (Australian Government Department of Human Services 2019c) - as any other Australian requesting assistance from Centrelink is able to do. This forces Aboriginal and Torres Strait Islander students to either spend hours on the phone (Conifer 2018), communicate via post, or physically attend a Centrelink office to apply for or manage their study allowance. Processing times for Indigenous-specific assistance packages can be unreasonably lengthy, too. While there is no publicly available data for ABSTUDY recipients, Australian students often wait significantly longer than Centrelink's stated processing time to have their claims assessed (McCormack 2018). It recently took over 50 business days - more than double Centrelink's stated processing time of 21 business days to process my claim for a type of Indigenous study assistance. While there is some intersection between the experiences of Indigenous and non-Indigenous Australians in 
accessing study assistance, it seems that the administration of ABSTUDY inconveniences, deters, and in some ways disempowers Aboriginal and Torres Strait Islander students more so than other students.

If ABSTUDY was created to address Indigenous educational disadvantage, CDEP was established by the Australian federal government to address employment and economic disadvantage. Like ABSTUDY, it has also had several reincarnations since the 1970s and is now called the Community Development Program (CDP). In 1997, Race Discrimination Commissioner Zita Antonios investigated allegations that the then-CDEP scheme was racially discriminatory. Antonios determined it was not racially discriminatory for two noteworthy reasons: The Racial Discrimination Act (1975) permitted such racially-specific programs under its provisions for 'special measures', which refer to laws or policies made for the 'benefit' of Aboriginal people; and the program is part of the broader 'enfranchisement' of Aboriginal and Torres Strait Islander people which followed the 1967 Referendum (Antonios 1997, p. 5). The concerns raised in the 1990s have, however, still not been mitigated today.

A 2018 submission from an Aboriginal Economic Policy Researcher to the Department of the Prime Minister and Cabinet identifies a series of standard employment entitlements usually enshrined in law, but not granted to CDP participants (Jordan 2018). These include, but are not limited to, superannuation, a minimum wage and leave entitlements (Campbell, Browne \& Grundoff 2018, Jordan 2018, p. 6). Aboriginal trade unionist Celeste Liddle has additionally likened the scheme to the historical exploitation of Aboriginal and Torres Strait Islander people through unfair and unpaid wages, and described it as 'free labour' for participating businesses since the majority-Indigenous CDP participants are remunerated with welfare payments rather than income from their employer (Liddle 2016). It is on this basis that Liddle explains CDP is failing to resolve wealth disparity between Indigenous and nonIndigenous Australians and cites 'a good portion of the country' turning a blind eye as a major contributing factor to the continuation of CDP (Liddle 2016). Antonios' findings against such serious concerns are symptomatic of what McKenna recognised as the 'long history of indifference, discrimination and injustice meted out to Indigenous Australians by colonial, state and federal governments' (2018, p. 13).

Yolngu man Galarrwuy Yunupingu, whose homeland was a focus of the most recent CDEP rollout, also rejected any benefit of the CDEP program for Aboriginal people. His firsthand account described it as 'destructive' (Yunupingu 2016) due to the power it bestowed lowlevel government employees over CDEP's Aboriginal and Torres Strait Islander participants and claimed it increased community dysfunction (Yunupingu 2016). Further to this, Langton listed CDEP as a 'shameful' scheme among other government initiatives that have been used to 'isolate the Aboriginal world from Australian economic and social life' (Langton 2013, p. 2). In this way, the CDEP scheme and its variants are paternalistic and punitive, for they restrict, penalise and exploit primarily Aboriginal welfare recipients in remote communities.

The aptly-named 2007 'Federal Intervention', enabled by the 1967 constitutional amendment, was and continues to be yet another intrusion into the lives of Aboriginal and Torres Strait

NEW: 2019 
Islander people. The publication of the findings of a government inquiry into child sex abuse in remote NT communities, entitled Little Children are Sacred, acted as a springboard for a host of hasty, oppressive Howard government actions, such as sending the military into remote Aboriginal communities, enforced quarantining of welfare payments, commandeering of Aboriginal-controlled land and banning alcohol consumption and pornography (Perche 2017). Such actions were controversially deemed 'special measures' under the Racial Discrimination Act (1975) regardless of the lack of consultation with, or consent from its purported beneficiaries (McCausland 2008, pp. 7-8). To eliminate any potential legal barriers, the federal government then chose to pre-emptively suspend the operation of the Racial Discrimination Act (1975) (Australian Human Rights Commission n.d.). Despite the scale of the government's response to the child abuse claims and the government's characterisation of it as a 'national emergency', in the period 2007-2012 only 45 people were convicted of child sex offences across the 73 communities affected by the Intervention (Gray 2015, p. 21; Perche 2017).

The Intervention was undertaken without the participation, consultation or informed consent of remote Aboriginal residents (McCausland 2008). The Intervention's legislation, Northern Territory National Emergency Response Act (2007), perpetuated stereotypes of Indigenous dysfunction, employed deficit discourse and was an affront on Indigenous sovereignty and self-determination. The Intervention was perhaps the most serious application of the constitutional changes triggered by the 1967 Referendum in recent decades. In 2012, the Intervention was renamed 'Stronger Futures', and its powers have been extended until 2022 by the current federal government (Korff 2019).

The establishment of the Northern Territory National Emergency Response Act (2007) and suspension of the Racial Discrimination Act (1975) epitomises the type of detrimental and 'extreme' legislative manoeuvres that, in the 1997 Hindmarsh Island Bridge Case, Justice Kirby was assured would never be enacted (Kirby 2007, pp. 4-5). Regrettably, when the High Court found that amendments to Section 51 (xxvi) of the Constitution empowered the federal government to legislate for the benefit or detriment of Aboriginal and Torres Strait Islander people, it emboldened successive governments to exercise the latter. This outcome does not reflect the ambitions of proponents of the Referendum, who declared that federal control of Indigenous legislation and policy would put an end to the 'havoc' being meted out by state governments and that the reforms would lead to a range of benefits for Indigenous people (Bandler 1989, p. 110).

As part of the Intervention, the income management tool 'BasicsCard' was introduced to facilitate the quarantining of half of all welfare payments in NT remote communities. Today, the federal government states that income management via the BasicsCard is an opt-in process (Australian Government Department of Human Services 2019b). Notwithstanding, it was imposed upon, rather than offered to Aboriginal and Torres Strait Islander people during the rollout of the Intervention (Gray 2015, p. 41; McCausland 2008, p. 11). Moreover, the welfare recipients' right to appeal such actions was removed with an amendment to the Social Security (Administration) Act (1999) (Gray 2015, p. 41). In doing so, the federal government 
overrode what little autonomy Aboriginal and Torres Strait Islander welfare recipients in NT remote communities had regarding their income.

The federal government's central justification for BasicsCard was that it would reduce alcohol, drug and gambling-related harm. However, evidence available at the time, as well as a comprehensive evaluation of the effectiveness of income management since the Intervention do not support such claims (Bray 2016; St Vincent de Paul Society 2019). Additionally, the BasicsCard and similar income management cards have been arbitrarily forced upon Aboriginal and Torres Strait Islander welfare recipients with no history of substance abuse problems (Stevens \& Moussalli 2019). Through the Basics Card, the federal government significantly restricts Aboriginal and Torres Strait Islander people's spending to only government-approved retailers, precludes the purchase of more affordable second-hand goods since users cannot withdraw cash, and stigmatises card users as financially irresponsible (St Vincent de Paul Society 2019). It is also more restrictive than the equivalent cashless welfare card available outside of NT remote Aboriginal communities, which allows cash withdrawals and can be used at any retailer that does not sell alcohol or gambling products (St Vincent de Paul Society 2019, p. 2). BasicsCard patronises Aboriginal and Torres Strait Islander welfare recipients by assuming they are unable to manage their financial affairs and treating them as dependant rather than sovereign beings.

Such attitudes are reminiscent of past government policies which were based on similar beliefs about Aboriginal and Torres Strait Islander peoples' entitlement to, and capacity to manage their own income, and led to an estimated hundreds of millions of dollars in stolen and unpaid wages (Fijn et al. 2012, p. 177). Since colonisation, Aboriginal and Torres Strait Islander people have been denied the opportunities enjoyed by non-Indigenous Australians to develop financial skills and participate fully in the Australian economy (Fijn et al. 2012). Thus, Aboriginal and Torres Strait Islander people - and especially Aboriginal and Torres Strait Islander welfare recipients - should be provided with options to improve their financial literacy rather than be punished for any perceived or actual financial difficulty with measures such as the BasicsCard. It was hoped the 1967 Referendum would liberate Aboriginal and Torres Strait Islander people from tyrannical state governments of the past, but it has simply transferred that power to the federal level.

Another paternalistic policy with the as-yet unfulfilled goal of controlling Aboriginal and Torres Strait Islander peoples' access to alcohol is the NT Banned Drinker Register, which requires the scanning of photo identification for all takeaway alcohol purchases in the NT, for the purposes of checking against a government list of prohibited buyers. This policy was initially implemented in 2011 by an NT Labor government before the Country Liberal party abolished it the following year (ABC News 2015). Federal ministers complained that the BDR's revocation was hindering progress of its Closing the Gap program, former Prime Minister Gillard warned that 'rivers of grog' would begin flowing back into Aboriginal communities (Macklin 2013), and a federal committee was later established which insisted on the BDR's reintroduction (ABC News 2015). This pressure led to the re-establishment of the 
BDR by a new NT Labor government in 2017, with the predictable support and encouragement of the federal government.

The BDR is an insidious policy for several reasons, and the federal government's involvement has only disadvantaged Aboriginal and Torres Strait Islander people further. The NT population is approximately $25 \%$ Aboriginal and Torres Strait Islander people (Australian Bureau of Statistics 2016) and most homeless Territorians are Aboriginal and/or Torres Strait Islander (Homelessness Australia 2014). The NT Government explains that placement on the BDR is mostly at the discretion of government staff or police (Northern Territory Government 2019) or is as a result of alcohol-related offences (Australian Indigenous HealthInfoNet 2018). Homeless Aboriginal and Torres Strait Islander people are disproportionately affected by these criteria, as their drinking and any associated offences are more visible, and therefore more likely to be reported than the NT's housed population who are privileged with the option of drinking in their homes. Furthermore, the BDR does not apply to online liquor sales, presumably because the NT Government expect that Aboriginal and Torres Strait Islander 'problem drinkers' will not have access to an unrestricted method of payment as well as a fixed address for delivery.

'Long-grassers', as the homeless Aboriginal and Torres Strait Islander people are colloquially known and self-described, have explained how they can easily obtain alcohol while on the BDR because they 'ask white people to buy it' (Thompson \& Cochrane 2018). This coupled with a link between alcohol consumption among long-grassers and transactional sex, which has led to abuse and incidents of rape (Holmes \& McRae-Williams 2012) indicates that the BDR has only increased the risk of harm for this vulnerable group of Aboriginal and/or Torres Strait Islander NT residents. Together, the NT and federal governments have established and re-established an expensive, ineffective and punitive system of controlling the purchase of alcohol, and in turn, created a reliance on non-Indigenous sexual predators to purchase alcohol on the long-grassers' behalf. Hence, the BDR exemplifies the perils of the federal government's intrusion into Aboriginal and Torres Strait Islander peoples' lives, as opposed to respecting their independence and employing genuine, evidence-based strategies to reduce alcohol-related harm.

The above examples have illustrated some of the many ways the federal government has used its power acquired through the 1967 Referendum to micromanage Aboriginal and Torres Strait Islander peoples' affairs. Despite the sentiments of the Australian public and 'yes' advocates during the Referendum, the federal government seems determined to maintain as much of its control of Aboriginal and Torres Strait Islander people as possible. The principles underpinning some of its decisions and legislation appear nostalgic for past State government policies, which saw Aboriginal and Torres Strait Islander people subjected to a high level of government control. Finally, the constitutional changes of the 1960s may have equipped the federal government with the legal means to act on its assumptions about Indigenous competence, but the 1997 High Court decision galvanised it.

The government's indifference towards Aboriginal and Torres Strait Islander peoples' sovereignty and self-determination has manifested in its inequitable treatment of Aboriginal

NEW: 2019 
and Torres Strait Islander students seeking a study allowance, its endorsed exploitation of Indigenous welfare recipients' labour, its disregard for Indigenous consultation or consent during the federal intervention, its exceptionally prescriptive welfare card for Indigenous communities, and its marginalisation of Aboriginal drinkers. It is this regressive denial and removal of Aboriginal and Torres Strait Islander peoples' choices that has inhibited public perception of Aboriginal and Torres Strait Islander people as functional, capable and autonomous.

\section{References}

ABC News 2015, 'Banned Drinker Register 'should be reinstated', Northern Territory Government's 'lack of cooperation' condemned', ABC News, 26 June, viewed 19 June 2019, <https://www.abc.net.au/news/2015-06-26/banned-drinking-register-should-be-reinstatedalcohol-report/6574422>.

Antonios, Z. 1997, The CDEP scheme and racial discrimination, Australian Human Rights Commission, Sydney, NSW, viewed 17 June 2019, $<$ https://www.humanrights.gov.au/sites/default/files/content/pdf/race_discrim/cdep_scheme.p df $>$.

Australian Broadcasting Corporation 2016, You can't ask that - Indigenous, ABC iView, viewed 18 June 2019, <https://iview.abc.net.au/show/you-can-t-askthat/series/1/video/LE1517H008S00>.

Australian Bureau of Statistics 2016, 2016 Census QuickStats, viewed 19 June 2019, $<$ https://quickstats.censusdata.abs.gov.au/census_services/getproduct/census/2016/quickstat/7 ?opendocument>.

Australian Government Department of Human Services 2019a, ABSTUDY - Eligibility, viewed 17 June 2019,

<https://www.humanservices.gov.au/individuals/services/centrelink/abstudy/eligibility .

Australian Government Department of Human Services 2019b, BasicsCard - Eligibility, viewed 18 June 2019,

<https://www.humanservices.gov.au/individuals/services/centrelink/abstudy/eligibility>.

Australian Government Department of Human Services 2019c, Claiming, viewed 17 June 2019,

<https://www.humanservices.gov.au/individuals/services/centrelink/abstudy/claiming>.

Australian Human Rights Commission n.d., The suspension and reinstatement of the RDA and Special Measures in the NTER, viewed 18 June 2019, $<$ https://www.humanrights.gov.au/our-work/suspension-and-reinstatement-rda-and-specialmeasures-nter-0>.

NEW: 2019 
Australian Indigenous HealthInfoNet 2018, Banned Drinker Register, viewed 19 June 2019, $<$ https://healthinfonet.ecu.edu.au/key-resources/programs-andprojects/3435/?title=Banned\%20Drinker\%20Register $>$.

Bandler, F. 1989, Turning the tide: a personal history of the Federal Council for the Advancement of Aborigines and Torres Strait Islanders, Aboriginal Studies Press, Canberra.

Bray, J. R. 2016, Income management evaluations - what do we know?, CAEPR working paper no. 111/2016, Australian National University, viewed 18 June 2019, <http://csrm.cass.anu.edu.au/sites/default/files/rsss/Income_mgmt_evals_Bray_Nov_16.pdf>.

Campbell, R., Browne, B. \& Grundoff, M. 2018, Remote control: The Community Development Program, remote Australia's Work for the Dole scheme, The Australia Institute, viewed 18 June 2019, <http://www.tai.org.au/sites/default/files/P448\%20Remote\%20control\%20FINAL.pdf>.

Conifer, D. 2018, 'Centrelink call wait times grow, with some clients waiting an hour on hold', ABC News, 23 January, viewed 17 June 2019, <https://www.abc.net.au/news/2018-0123/centrelink-call-wait-times-balloon/9351450>.

Fijn, N., Keen, I., Lloyd, C., \& Pickering, M. (eds) 2012, Indigenous participation in Australian economies, II: Historical engagements and current enterprises, ANU Press, Canberra.

Gray, S. 2015, The Northern Territory Intervention: An evaluation, Monash University, viewed 18 June 2019, <https://www.monash.edu/_data/assets/pdf_file/0008/406943/Caitlinedit-of-NT-Intervention-page-1.pdf $>$.

Holmes, C. \& McRae-Williams, E. 2012, 'Captains' and 'Selly-welly': Indigenous women and the role of transactional sex in homelessness, Batchelor Institute of Indigenous Tertiary Education, viewed 19 June 2019, <http://eprints.batchelor.edu.au/297/1/Homelessness_Report_v2_1_Print.pdf>.

Homelessness Australia 2014, Homelessness in the Northern Territory, viewed 19 June 2019, <https://www.homelessnessaustralia.org.au/sites/homelessnessaus/files/2017-07/NT__updated_Jan_2014.pdf>.

Jordan, K. 2018, Response to PM\&C discussion paper: Remote employment and participation, Department of the Prime Minister and Cabinet, viewed 17 June 2019, $<$ https://pmc.gov.au/sites/default/files/public-submissions/remote-employment2018/Dr\%20Kirrily\%20Jordan.pdf>.

Kirby, M. 2007, The 1967 Referendum: Don't get carried away, High Court of Australia, viewed 18 June 2019, <http://www.hcourt.gov.au/assets/publications/speeches/formerjustices/kirbyj/kirbyj_1jun07.pdf>. 
Korff, J. 2019, Northern Territory Emergency Response (NTER) - "The Intervention", Creative Spirits, viewed 18 June 2019, $<$ https://www.creativespirits.info/aboriginalculture/politics/northern-territory-emergencyresponse-intervention>.

Langton, M. 2013, 'Indigenous exceptionalism and the constitutional "race power", in $\mathrm{H}$. Sykes (ed.), Space, Place and Culture, Future Leaders, Albert Park, Victoria, pp. 1:1-20.

Liddle, C. 2016, 'Aboriginal workers still slipping through the gaps', Eureka Street, 2 December, viewed 17 June 2019, <https://www.eurekastreet.com.au/article/aboriginalworkers-still-slipping-through-the-gaps $>$.

Macklin, J. 2013, Alcohol, NT Banned Drinking Register, Closing the Gap, Commonwealth of Australia, viewed 19 June 2019, <https://formerministers.dss.gov.au/13212/alcohol-ntbanned-drinking-register-closing-the-gap >.

McCausland, R. 2008, International human rights principles and the Northern Territory National Emergency Response Legislation, University of Technology Sydney, viewed 18 June 2019, <https://www.uts.edu.au/sites/default/files/JIHLBP9_0.pdf >.

McCormack, A. 2018, 'Semester's over, but students are still waiting for Centrelink claims to be processed', Triple J Hack, 26 June, viewed 17 June 2019, <https://www.abc.net.au/triplej/programs/hack/centrelink-student-wait-times/9911522>.

McGregor, R., 2009, 'Another nation: Aboriginal activism in the late 1960s and early 1970s', Australian Historical Studies, vol.40, no.2, September, pp.343-360.

McKenna, M. 2018, 'Moment of truth: History and Australia's future', Quarterly Essay, no. 69, pp. 1-86.

Northern Territory Government 2019, Banned Drinker Register(BDR), viewed 19 June 2019, $<$ https://health.nt.gov.au/professionals/alcohol-and-other-drugs-health-professionals/alcoholfor-health-professionals/banned-drinker-register>.

Northern Territory National Emergency Response Act 2007 (Cth).

Perche, D. 2017, 'Ten years on, it's time we learned the lessons from the failed Northern Territory Intervention', The Conversation, 26 June, viewed 18 June 2019, < http://theconversation.com/ten-years-on-its-time-we-learned-the-lessons-from-the-failednorthern-territory-intervention-79198> .

Racial Discrimination Act 1975 (Cth).

Richardson, J. 1998, 'Money and study: Abstudy and the right to review', Indigenous Law Bulletin, vol. 4, no. 11, viewed 17 June 2019, <http://www8.austlii.edu.au/cgibin/viewdoc/au/journals/ILB/1998/37.html>. 
Social Security (Administration) Act 1999 (Cth).

St Vincent de Paul Society 2019, Briefing: What's wrong with the cashless debit card?, viewed 18 June 2019,

$<$ https://www.vinnies.org.au/icms_docs/279095_Cashless_Welfare_Card_Briefing_Dec2017. pdf $>$.

Stevens, R. \& Moussalli, I. 2019, 'Cashless debit card trials are being extended, but are they even working?', $A B C$ News, 4 April, viewed 18 June 2019,

<https://www.abc.net.au/news/2019-04-04/cashless-debit-card-trials-extended-but-do-theyeven-work/10966900>.

Thompson, J. \& Cochrane, L. 2018, 'Long-grassers' admit easy access to grog despite reintroduction of banned drinker register', $A B C$ News, 11 September, viewed 19 June 2019, <https://www.abc.net.au/news/2018-09-11/easy-access-to-grog-despite-nt-banned-drinkerregister/10221900>.

Yunupingu, G. 2016, 'Rom watangu: The law of the land', The Monthly, July, viewed 16 May 2019, <https://www.themonthly.com.au/issue/2016/july/1467295200/galarrwuyyunupingu/rom-watangu>. 